\title{
OUR TRIPS TO CHINA
}

\author{
GABY BOREL
}

\section{In deep memory of Armand (Borel)}

What an unforgettable life I spent with my husband Armand Borel.

We met in Zürich, married in Geneva and moved to the States. Both of us loved to travel and thanks to some math conferences visited, among other countries, China.

Our first trip there was in 1981. After landing in Beijing, where we were received like a king and queen and taken to a V.I.P. room, we were invited to have tea in those lovely cups covered with a lid. Never seen before! We were then taken to the Friendship hotel and Armand started with his talks the following day. We fell in love with the people and visited the classical Beijing monuments. Our highly cultivated interpreter and guide, Shiu Itzuch Shu, made us visit all the beautiful monuments and fascinating temples, full of paintings and sculptures of the period - The Forbidden City, Temple of Heaven, Lama Temple, Five Pagoda Temple (very Indian)! We were very impressed by all we saw - the Temple of Mel Source and Hulaw and Universal Rescue. It was also fun to visit the Peking man's cave. While playing with some stones, I found myself holding a small-petrified bone, obviously human - from the Peking man? Just like the ones in the museum, 500,000 years old!

Our interpreter is unforgettable as well as his wife and children. The children are big now and we met again later. It felt like family (one of his daughters in a later year even gave Armand a haircut). We had also a very nice chauffeur and his wife, very young too, Yan Quing Sue. I still can see the lovely Lugou Bridge described by Marco Polo in the 13th century.

From Beijing we went to Tianjin for a visit. There I was invited to visit a carpet factory. But I had seen some young girls rehearsing dance on street corners so I decided to attend their festival instead. It was the International School Celebration. Out of this world! The children produced dance from various parts of China, and when I came back to the States we had a very nice correspondence together. I got letters from teachers and pupils.

During the Introduction to Arithmetic Groups conference we went to Luoyang and saw breathtaking Longmen Grottoes from the sixth century, Song Tomb!!! Located $12 \mathrm{~km}$ away from Luoyang City we saw a presentation of the horse of the monk who brought Buddhism from India to China and visited Xi'an to see the sculptures of the army, so amazing! We saw big gorgeous tombs. Qian Ling, Wu Zetian, Princess Li Xianhui 7th century, beautiful paintings. It is impossible to describe everything - no time!

At Shanghai East University, I visited schools while Armand was giving talks and went into a temple in the old city that turned out to be a school. The teacher offered me tea in a marmalade jar and a pupil played Pipa and danced. Very gifted! I had a wonderful time! We visited Shanghai port, Huang Pu River and went to Hangzhou. The caves are beautiful, though some sculptures are broken due to the Cultural Revolution. Hangzhou is such a romantic city! We went to the top of Lingya, Suzhou with its picturesque canal, colorful boats; Guilin and it's mountains like in the Chinese paintings; down the Ling Canal with its dam from $220 \mathrm{BC}$ and to the 
tomb built in memory of the last general who finished building the dam. What a nice ride on the canal. We met Japanese girls who told us they had found their roots in China and later wrote to us.

And then: off on a flight to Canton. (See the photo of Maoist Armand with nice girls!)

Arriving in Hong Kong for the first time, Prof. Lai met us, and we loved being there too! What a nice reception!

We went three more times to China and always had a fascinating time. In 1993 we went to Dunhuang from Lanzhou, crossed part of the Gobi desert, visited a tomb whose roof was at floor level and found a miniature palace after having gone down steps. The Great Wall was on the way and an important corner was restored. Some camels were there to give us a ride. In fact someone tried to sell me a camel for 600 Yuan's. I don't think it was in the greatest shape or that Armand would have been too pleased. After a few days (not on camel) we reached Dunhuang and saw many caves depicting Buddha's life from the 4 th to the 13 th century. What a discovery and what great art. Armand met with the head of the archeological team there. She and Armand had such an in depth discussion that we were invited to see several caves not open to the public. These particular caves are very small and, as the breath potentially erodes cave paintings, the general public is not allowed to access them. Seeing them was an unbelievable experience.

In 1998 we were at Peking University. We had a warm reception by Professor Wang and a nice room at the University. At night we shared a delicious meal with Professor $\mathrm{Lu}$ and the mathematicians of the department.

Among other things we celebrated Professor Lu's birthday on May 16th and Armand's on May 21st.

Professor Wang took us to the Five Pagodas Temple: it seemed so Indian, more than Great Bell (Ming) Temple. All of them, from different periods, are so refined. Then came pleasant walks among ponds and the lovely Chinese buildings of Peking University grounds.

On May 17th we made a new friend, we met Marianne who sings in a Jazz ensemble and is very good. Armand was enchanted!

The next day we had an excellent meal at a place recommended by Marianne, and then visited the Temple of Heaven, always breathtaking! And the ancient Summer Palace with lakes dating 100 years back.

May 20th again we saw the Great Wall at Mutianyu and had a very big meal at California Restaurant, listening to Marianne and her orchestra. Back only at 11:00 pm, we had so much fun!

May 21st went shopping with Shum who is still very good looking. At noon we ate with him and the driver, and that evening we had a super top meal (Armand always said that the food in China "was in a class by itself") with former President Ding and his wife, a chemist, both beautiful and "tres sympathique"!

May 22nd we visit the Tanzhe-si where we admire famous ginkgo, magnificent temples and a cemetery with nice pagodas and Srypas; visit Jietai-si, a temple with a tall Buddha which is most venerated in China and in gorgeous shape. Later we had a nice dinner given by the Institute of Mathematics and School of Mathematical Science of Peking by Zhang Jiping, Peng Lizhung, Guo Maozheng, and Tan Xiaojiang. 
May 23rd is dedicated to mathematics. Sacred atmosphere! There we both take a nice walk and eat a vegetable soup at home.

May 24th in the afternoon, we visit the Great Lama Temple with 24 meter high Buddha sculpted from a whole Sandalwood tress.

May 25th Rest!!!

May 26th is the discovery of the Mosque of Beijing so interesting and full of charm; Fayuan-si where we meet very interesting smiling monks who show us the whole complex, including the dining rooms. That night, a divine meal in the park is offered to us by five mathematicians.

May 27th Shu takes us to his house to eat exquisite food prepared by his wife. His eldest daughter, Lily, cuts Armand's hair. I don't know where the photographs of this lovely event are, but they exist.

May 28th departure for Datong. Visit of the famous Buddhist caves. Some sculptures still have paint and were achieved from 443 to $525 \mathrm{BC}$ - gorgeous and very refined! Hail China!

Back to Beijing on the 31st and that evening, another fantastic meal!

June 1st we leave for Shanghai where we get a cute and simple apartment and decide to get no maid. Armand develops a taste for concubines; six beautiful girls serve us in the cafeteria.

In the middle of the campus sits a Mao statue in a domineering and impressive pose.

June 2nd we visit the Museum and see famous rare bronzes!

June 3rd, 4th and 5th are for walks and shopping while Armand is working.

June 6th we visit the Jade Buddha Temple crowned by worshippers from all over.

June 7th Packing.

June 8th we leave for Yunnan and our first stay at Kunming University Guest House and then the Rice Hotel. We meet very clever ladies that have potential for math, who embroider pillow covers in a very geometrical fashion. Beautiful! Could not resist! Interesting temples too! As well as a zoo!

June 10th off to the fairytale like Stone Forest where we meet girls in typical costumes and find fossils. I have always loved fossils!

June 12th take tours on big lake. We visit villages with houses adorned by shaded sort of grayish marble. Quite elegant! Four famous pagodas are nearby. Above a lake complex are a variety of sculptures and small temples. Extremely picturesque!

We leave Kunming on July 1st and fly to Hong Kong. Impressive arrival at the old airport. We could have landed on top of a building, unless we hit it.

Cheng and Yau are expecting us. We are taken to a nice two-bedroom in a very modern building at the Chinese University. The next day Armand gives his lecture at 11:00 and then goes for a swim. Yau invites us with the Chengs for a delicious meal.

July 4th Yau shows us the village and the house where he was born - full of charm - and we climb to a very modern, amusing and nice Buddhist temple. Visit also Stanley, the big shopping area. What a discovery! And back to Switzerland.

In June 1998 we stopped in Hong Kong to investigate a stay there. The Moks persuaded us that we would like it and received us so well. We felt enchanted. 
We start the first of our three annual four month stays in February 1999, and once again get a warm welcome from Julia and Ngaiming Mok who make us taste the delicious fish of Lamma Island and show us around.

Pretty fast we realize the wonderful possibilities offered by Hong Kong and its surroundings. Also, we have a beautiful apartment overlooking the bay with all the boat traffic and cargos. Fascinating! Cargos that look like diamonds at night. The skyscrapers are gorgeous.

That April 18th we have tea at the Moks with Lie Koe Goodman and Henriguetta, and we take a boat ride among the houseboats in Aberdeen. Another day we go to the temple where people are doing their offerings and prayers. In June there is the Dragon Boat Race. First time we went to Sai Kung, then to Aberdeen, so fantastic!!

On our way to the Peak we meet Philippino girls. They invite us for Father's Day. We became friendly with a number of them. They call us Mom and Dad, and a few stay in touch with us until today.

We went to Wong Shek at Chek Keng Sai Kung East Country Park and back to Ma Liu Shui. How beautiful. There are wild cows there. Nature is full of glory!

So many things: We went to Tinhau's birthday (Goddess of the sea). In May 2001, there is also the Dragon Boat Race at Lamma Island. On a Sunday we go to Po Toi Island. It's a fisherman island, open only on Sundays to tourists. And we go to the Bun Festival on Cheung Chau Island.

There is a math congress in Tunxi, so we decide to climb the Yellow mountains.

But I am tired, so good night!

We fell in love with Mainland China, Hong Kong and their people and were planning to see more, hoping to discover remote places with ancient traditions, maybe high up in the mountains.

Our heartfelt thanks to all of you who made our sojourns so unforgettable. What an interesting time you made us have!

We would have liked to know some of the languages!

With warmest wishes! 